\title{
Motivation Role in Improving Work Effectiveness
}

\author{
Yeti Kuswati \\ Lecturer at Public Administration - Majalengka University \\ yeti.kuswati@yahoo.co.id
}

\begin{abstract}
In an effort to realize the vision of the Regional Technical Implementation Unit (UPTD) of Irrigation Network at Talaga, Majalengka, which is "providing optimal and maximum service in the field of irrigation to the public", it is needed a motivation from the Head of the UPTD so that employees can actively and enthusiastically carry out management, utilization, and services of irrigation. Based on observations, it turned out that the effectiveness of employee's work in irrigation management is still not optimal (still low). The problem was because the implementation of motivation by Head of the UPTD is not based on the principles of motivation maximally. This research was conducted at the UPTD of Irrigation Network at Talaga, Majalengka, using a theoretical basis on motivation with the parameters of principles of motivation proposed by Malayu S.P. Hasibuan and for the measurement of work effectiveness using indicators according to Gibson which are production, quality, efficiency, flexibility, and satisfaction. The analytical method used was a quantitative analysis method using quantitative descriptive analysis techniques, scoring, and crosstab. In this study, the sample used was random sampling. The results of the study found that the implementation of motivation by Head of the UPTD only reached $60.3 \%$, having predicate "Good Enough". Meanwhile, work effectiveness of new employees reached 59.3\%, having predicate "Good Enough". Therefore, motivation has not been maximally implemented in which it resulting in the effectiveness of employee's work also still cannot be improved optimally.
\end{abstract}

Keywords: Motivation; leadership; work effectiveness.

\section{Introduction}

The development of water resources in Indonesia is always experiencing an increase and change from time to time. Therefore, it is very necessary to develop and improve the water resources sector both in terms of policies, regulations, institutional aspects, and implementation in the field. The reformation in the water resources management is one of the important actions to overcome poverty alleviation, food security, and conservation of natural resources. In its implementation, several policies have been issued including the enactment of Regulations Number 7 of 2004 concerning Water Resources (Regulation of Water Resources). The Regulation of Water Resources states vision, mission, and principles of water resource management in Indonesia. The vision for water resources management under the Regulation of Water Resources is "Water resources are managed thoroughly, integrally, and environmentally friendly by the purpose of realizing the utilization of sustainable water resources for the prosperity of the people as much as possible" (Article 3 of the Regulation of Water Resources). To carry out this vision, five water resource management missions have been identified, which are as follows:

- conservation of water resources,

- utilization of water resources;

- control of water damage;

- empowerment and enhancement of the role of the community, business world, and government; and

- Improvement of data and information which is availability and transparency. 
To realize the vision and the mission of District Government of Majalengka through District Regulation of Majalengka Number 10 of 2009 concerning the Organization of the Majalengka District, stating that the implementation of water resources management in the Majalengka District is regulated and handled by the Water Resources Management Agency. In order to realize the mission of water resources management, high work productivity is required from the field officers of UPTD of Regional Irrigation Network so that the implementation of water resources management can run well, and the organizational goals can be achieved.

Based on observations made by researcher in the UPTD of Irrigation Network at Talaga, Majalengka, apparently, there are still symptoms of problems indicating that the effectiveness of employee's work in the UPTD of Irrigation Network at Talaga was still low. The problem is suspected to be caused by Head of the UPTD has not yet fully applying the principles of motivation in implementing motivation. Meanwhile, the results of previous researches have empirically proven that motivational factors can improve work outcomes more effectively for organizations (Manzoor 2011), and it can improve its performance (Ek and Mukuru 2013; Francis and Corresponding 2012; Robescu and Iancu 2016). It has shown that motivational factors are very important for employees (Rožman, Treven, and čančer 2017).

\section{Review of Literature}

\subsection{Motivation}

In life, motivation has a very important role because motivation is an entity causing, channelling, and supporting human behaviour, so that they want to work hard and enthusiastically to achieve the optimal results. Likewise, in the world of work, motivation plays an important role in achieving the organizational goals. Motivation is important because, by having this motivation, it is expected that each individual of employee is willing to work hard and enthusiastically to achieve high work productivity. Motivation comes from the Latin word "movere" meaning "impulse or driving force". This motivation is given to humans, especially to subordinates. Related to this, what is meant by motivation is to question how to encourage the enthusiasm of subordinates' work, so that they want to work hard by giving all their abilities and skills to realize organizational goals. Motivation is the whole process of giving encouragement to subordinates to work in such a way so that they want to work with sincerity, and the achievement of efficient and economical organizational goals can be achieved (Siagian, Sondang. 2008).

From the above experts' opinions, it can be concluded that motivation is the process of giving motives, encouragement, or stimulation to subordinates so that they want to work consciously and sincerely as well as have passion in the effort to achieve organizational goals. To motivate employees or subordinates, the organization leadership must know the motives and motivations desired by the employees. There are many kinds of motivations such as giving proper and fair compensation, giving awards, and so on. This is intended so that whatever the employee's needs can be met. Then, it is expected that the employees can work well and feel happy with all the tasks that they carry. Motivation from the leadership to subordinates can give satisfaction to the employees (Rožman, Treven, and čančer 2017; Zafar 2014). After employees feel satisfied with their work, employees will respect each other's 
rights and obligations so that a conducive work atmosphere is created. Ultimately, employees voluntarily and sincerely provide their best abilities in carrying out their duties and responsibilities.

\subsection{Work Effectiveness}

In the world of work, employees are required to have high work effectiveness. Organizational effectiveness is usually interpreted as the success achieved by an organization in its efforts to achieve predetermined goals. As the opinion of (Gibson, James L. 2006) saying that the effectiveness is "the achievement of goals set by cooperative effort". Clearly, if the target or goal has been achieved as it is planned before, it is called effective. Thus, if the target or goal is not completed within the allotted time, the work is not effective. The success and failure of an organization to achieve its intended goals depends on the ability of employees to carry out their duties and responsibilities for the assigned tasks to them. If the work results are in accordance with what has been determined, the situation can be said to be effective (Kataria 2013).

(Sugandha 1991) put forward the opinion that effectiveness is a successful work to achieve predetermined goals, because the word "effective" is a state of success in achieving targets or goals that are really useful. While (Handayaningrat 2002) provides an explanation that effectiveness is a measurement in the sense of achieving the predetermined targets or goals. Clearly, if the target or goal has been achieved as it is planned before, it is called effective. In its principle, the definition of effectiveness is an assessment of whether an activity/a system is achieved or not.

\subsection{Thinking Framework}

Motivation is an impulse generated both from internal and external influences. The most effective motivation for an organization is its leader (Rahbi 2017). Motivation owned by employees will have a positive impact on an organization in improving its performance (Dobre 2013; Mahamad and Saad 2018), it is because, with the motivation, employees will work more effectively (Kassa 2015), with the motivation, it can affect the quality of service (Syamsir 2016). In this study, indicators of motivation are the principle of participation, the communication principle, the principle of recognition, the principle of delegated authority, and the principle of mutual attention (Siagian, Sondang. 2008). As for the indicators of effectiveness in an organization are factors of production, quality, efficiency, flexibility, and satisfaction (Gibson, James L. 2006).

\section{Research Methods}

This study is a quantitative descriptive research. It is because this study describes the situation that occurs at the moment systematically and factually with the purpose to describe and to resolve the studied problem. In this study, quantitative descriptive method is the method used in completing a scientific study with the purpose to solve the problem being studied which is motivation role in improving work effectiveness. It is done by describing or explaining the facts obtained based on data and facts collected in the UPTD of Irrigation Network at Talaga, Majalengka. This study used population research because the subject is less than 100, precisely, it is 30 people. In accordance with the above opinion, the entire population is used as a research sample. To describe the data on each of the assessment 
variables is done by compiling a frequency distribution table to find out whether the level of obtained value (score) of the research variables is included in the categories: Strongly agree, Agree, Neither agree nor disagree, Disagree, Strongly disagree.

\section{Discussion}

In the implementation of management and services of irrigation, it is needed employees being able to work well and having high work effectiveness so that the work can run smoothly. The implementation of motivation in increasing the work effectiveness of employees of UPTD of Irrigation Network at Talaga conducted by Head of the UPTD must be based on the principles of motivation, so that the implementation can be organized and directed in order to achieve maximum results for the achievement of organizational goals. Regarding the principles of motivation applied by Head of the UPTD in the implementation of her/his motivation are as follows:

- The principle of participation

- The principle of communication

- The principle of recognition

- The principle of delegated authority

- The principle of mutual attention

To find out the implementation of motivation carried out by Head of the UPTD based on the implementation of the principles of motivation in order to increase the work effectiveness of employees of UPTD of Irrigation Network at Talaga, Majalengka, the researchers describe the implementation of the principles of motivation by the Head of the UPTD, as in the following table:

Table 1. Recapitulation of the implementation of the principles of motivation by Head of the UPTD of Irrigation Network at Talaga, Majalengka

\begin{tabular}{|c|l|cc|}
\hline \multirow{2}{*}{ No. } & \multicolumn{1}{|c|}{ Question Indicator } & \multicolumn{2}{|c|}{ Total } \\
\cline { 2 - 4 } & & F & $\%$ \\
\hline 1. & The principle of participation & & \\
- The opportunity to participate in the decision-making process & 16 & 53,3 \\
- Be open to suggestions or opinions expressed by employees & 15 & 50 \\
2. & The principle of communication & & \\
- Creating good communication in the workplace & & \\
- Providing information for employees & 22 & 73,3 \\
The principle of recognition & 21 & 70 \\
- Giving material rewards to outstanding employees & & \\
- Giving non-material rewards to outstanding employees & 15 & 50 \\
Principle of authority & 16 & 53,3 \\
- Growing confidence within employees who receive delegation of & & \\
authority & 20 & 66,7 \\
- Giving delegation of authority to the right employees & 19 & 63,3
\end{tabular}




\begin{tabular}{|c|c|c|c|}
\hline 5. & $\begin{array}{l}\text { The principle of mutual attention } \\
\text { - Creating a harmonious workplace } \\
\text { - Paying attention to employee self-actualization }\end{array}$ & $\begin{array}{l}21 \\
16\end{array}$ & $\begin{array}{c}70 \\
53,3\end{array}$ \\
\hline & Total & 181 & 603.2 \\
\hline & Average $=603,2: 10$ & & 60.3 \\
\hline
\end{tabular}

Source: Research results of 2019

Based on the recapitulation of the explanation of the principles of motivation mentioned above, it can be seen that the average value has only reached $60.3 \%$, if it is connected with the assessment standard of data analysis, it has reached the predicate "Good Enough". Thus, it can be concluded that it turns out that the Head of UPTD of Irrigation Network at Talaga, Majalengka, in the implementation of his motivation still has not fully implemented the principles of motivation. As for the value and predicate of the implementation of each principle of motivation by Head of UPTD of Irrigation Network at Talaga, Majalengka, it can be described as follows:

- The principle of participation, has an average value of two indicators of $51.6 \%$ which is "Poor".

- The principle of communication, has an average value of two indicators of $71.6 \%$ which is "Good Enough".

- The principle of recognition has an average value of two indicators of 51.6\% which is "Poor".

- The principle of authority, has an average value of two indicators of $65 \%$ which is "Good Enough".

- The principle of mutual attention, has an average value of two indicators of $65 \%$ which is "Good Enough".

Furthermore, to prove that the implementation of motivation has an effect on the increasing of the work effectiveness of employee, researchers conduct research on the dimensions of work effectiveness of employee which are as follows:

- Production

- Quality

- Efficiency

- Flexibility

- Satisfaction

From the overall response on indicators of work effectiveness of employee working in UPTD of Irrigation Network at Talaga, Majalengka, it appears that the level of work effectiveness is quite good, for more details about the achieving predicate of work effectiveness of employee can be seen through the following table:

Table 2. Recapitulation of the Achievement Level of Work Effectiveness

\begin{tabular}{|c|l|c|c|}
\hline \multirow{2}{*}{ No. } & \multicolumn{2}{|c|}{ Work Effectiveness } & \multicolumn{2}{|c|}{ Total } \\
\cline { 3 - 4 } & & $\mathrm{F}$ & $\%$ \\
\hline 1. & Production &
\end{tabular}




\begin{tabular}{|c|c|c|c|}
\hline & $\begin{array}{l}\text { - The results of the work in accordance with the targets and } \\
\text { conditions } \\
\text { - The results of work carried out in accordance with the expected } \\
\text { goals }\end{array}$ & $\begin{array}{l}22 \\
19\end{array}$ & $\begin{array}{l}73,3 \\
63,3\end{array}$ \\
\hline 2. & $\begin{array}{l}\text { Quality } \\
\text { - The work results meet the needs of the community } \\
\text { - Work is carried out based on work procedures and principles of } \\
\text { justice }\end{array}$ & 18 & $\begin{array}{l}63,3 \\
60\end{array}$ \\
\hline 3. & $\begin{array}{l}\text { Efficiency } \\
\text { - Implementation of work is done sparingly and within budget } \\
\text { - Implementation of work is carried out on time }\end{array}$ & $\begin{array}{l}20 \\
17\end{array}$ & $\begin{array}{l}66,7 \\
53,3\end{array}$ \\
\hline 4. & $\begin{array}{l}\text { Flexibility } \\
\text { - Increased employee ability to operate technology } \\
\text { - Increased services in accordance with community needs }\end{array}$ & $\begin{array}{l}16 \\
16\end{array}$ & $\begin{array}{l}53,3 \\
53,3\end{array}$ \\
\hline 5. & $\begin{array}{l}\text { Satisfaction } \\
\text { - The work results meet the needs of employees } \\
\text { - The work results provide community satisfaction }\end{array}$ & $\begin{array}{l}16 \\
15\end{array}$ & $\begin{array}{c}53,3 \\
50\end{array}$ \\
\hline & Total & 178 & 593,2 \\
\hline & Average $=593,2: 10$ & & 59.3 \\
\hline
\end{tabular}

Source: Research results of 2019

Based on the results of the recapitulation of the achievement level of work effectiveness of employee above, it turns out that the effectiveness of employees working in UPTD of Irrigation Network at Talaga has not yet fully increased. It can be proven by an average value of $59.3 \%$ or based on data analysis assessment standards, the work effectiveness of employee working in UPTD of Irrigation Network at Talaga achieves the predicate "Good Enough". As for the value and predicate of work effectiveness of employee working in UPTD of Irrigation Network at Talaga, Majalengka, it can be described as follows:

- Production, an average value of $68.3 \%$ which is "Good Enough".

- Quality, an average score of 61.6\% which is "Good Enough".

- Efficiency, an average value of $61.7 \%$ which is "Good Enough".

- Flexibility, an average score of 53.3\% which is "Poor".

- Satisfaction, an average value of $51.6 \%$ which is "Poor".

Head of the UPTD and the increase in work effectiveness of employee can be concluded that the implementation of motivation carried out by Head of the UPTD based on the implementation of the principles of motivation has a parallel relationship with the increase in work effectiveness of employee. It can be seen from the recapitulation of the average value of the implementation of the principles reaching an average value of $60.3 \%$ with the predicate "Good Enough", and the work effectiveness of new employees reaching an average of 59.3\% with the predicate "Good Enough" as well. The results of the study provide reinforcement to the results of previous researches (Olusadum and Anulika 2018) showing that motivation is very effective in improving employee performance which ultimately affects organizational performance (Lee et al. 2016). 


\section{Conclusion}

The implementation of motivation based on the principles of motivation by the Head of the UPTD was only $60.3 \%$ with the predicate "Good Enough". It is a proof that the principles of motivation have not been fully implemented by the Head of the UPTD. The implementation of the work effectiveness of new employees reached $59.3 \%$ with the predicate "Good Enough". The implementation of motivation in increasing the work effectiveness of employees working in UPTD of Irrigation Network at Talaga, Majalengka, apparently, Head of the UPTD has not fully implemented the principles of motivation, so that it has a parallel relationship with efforts to improve the work effectiveness of employees working in UPTD of Irrigation Network at Talaga, Majalengka. This is evident from the results of the implementation of the principles of motivation reaching $60.3 \%$ with the predicate "Good Enough" and work effectiveness of employee reaching 59.3\% with the predicate "Good Enough" as well. On the basis of the conclusions in which the researchers have put forward, the results of this study were taken into consideration by Head of the UPTD in an effort to increase the work effectiveness of employees working in UPTD of Irrigation Network at Talaga, Majalengka.

\section{References}

Dobre, Ovidiu-iliuta. (2013). "Employee Motivation and Organizational Performance." 5(1): 53-60.

Ek, Kiruja, and Elegwa Mukuru. (2013). "Effect of Motivation on Employee Performance In Public Middle Level Technical Training Institutions In Kenya.” International Journal of Advances in Management and Economics 2(4): 73-82.

Francis, Chukwudi, and Anyim Corresponding. (2012). "Motivation and Employees ' Performance in the Public and Private Sectors in Nigeria." International Journal of Business Administration 3(1): 31-40.

Gibson, James L., John M. Ivancevich and James H. Donnely Jr. (2006). Organisasi: Perilaku, Struktur, Proses. (Terjemahan) Edisi Delapan. 8th ed. Jakarta: Binarupa Aksara.

Handayaningrat, Soewarno. (2002). Pengantar Studi Ilmu Administrasi Dan Manajemen. Jakarta: Gunung Agung.

Kassa, Tizazu. (2015). "Employee Motivation and Its Effect on Employee Retention In." 3(3): 10-21.

Kataria, Aakanksha. (2013). "Employee Engagement and Organizational Effectiveness : The Role of Organizational Citizenship Behavior." 6(1).

Lee, Michael T, Robyn L Raschke, Michael T Lee, and Robyn L Raschke. (2016). "Understanding Employee Motivation and Organizational Performance : Arguments for a Set- Theoretic Approach Journal of Innovation Set-Theoretic Approach."

Mahamad, Datuk, and Seeht Saad. (2018). "Impact of Employee Motivation on Work Performance." 8(3): 295-308.

Manzoor, Quratul-ain. (2011). "Impact of Employees Motivation on Organizational Effectiveness." European Journal of Business and Management 3(3): 36-45.

Olusadum, Nnaeto Japhet, and Ndoh Juliet Anulika. (2018). "Impact of Motivation on 
Employee Performance : A Study of Alvan Ikoku Federal College of Eduaction." 9(1): 53-65.

Rahbi, Dana Al. (2017). “The Effects of Leadership Styles on Team Motivation.” 16(2): 114.

Robescu, Ofelia, and Alina-georgiana Iancu. (2016). "The Effects of Motivation on Employees Performance in Organizations." Valahian Journal of Economic Studies 7(2): 49-56.

Rožman, Maja, Sonja Treven, and Vesna Čančer. (2017). "Motivation and Satisfaction of Employees in the Workplace." Business Systems Research 8(2): 14-25.

Siagian, Sondang., P. (2008). Manajemen Sumber Daya Manusia (Edisi Pertama). Jakarta: Binapura Aksara.

Sugandha, Dann. (1991). Koordinasi Alat Pemersatu Gerak Administrasi. Jakarta: Intermedia.

Syamsir. (2016). "The Influence of Public Service Motivation on Service Quality of Civil Servants in West Sumatra Indonesia." European Journal of Economics and Business Studies 9571(August): 33-41.

Zafar, Nida. (2014). "Determinants of Employee Motivation and Its Impact on Knowledge Transfer and Job Satisfaction.” International Journal of Human Resource Studies 4(3): $50-69$. 